\title{
Older age does not influence CD4 cell recovery in HIV-I infected patients receiving Highly Active Anti Retroviral Therapy Mario Tumbarello*1, Ricardo Rabagliati ${ }^{2}$, Katleen de Gaetano Donati ${ }^{1}$, Silvia Bertagnolio ${ }^{1}$, Eva Montuori ${ }^{1}$, Enrica Tamburrini ${ }^{1}$, Evelina Tacconelli ${ }^{1}$ and Roberto Cauda ${ }^{1}$
}

\author{
Address: ${ }^{1}$ Department of Infectious Diseases, Catholic University, Rome, Italy and ${ }^{2}$ On leave of absence from the Department of Internal Medicine, \\ Pontificia Universidad Catolica de Chile, Santiago, Chile \\ Email: Mario Tumbarello* - tumbarello@rm.unicatt.it; Ricardo Rabagliati - rabagli@med.puc.cl; Katleen de Gaetano \\ Donati - kdegaetanodonati@yahoo.com; Silvia Bertagnolio - bertagnolios@who.int; Eva Montuori - eva.montuori@libero.it; \\ Enrica Tamburrini - enricatamburrini@rm.unicatt.it; Evelina Tacconelli - etaccone@bidmc.harvard.edu; Roberto Cauda - rcauda@rm.unicatt.it \\ * Corresponding author
}

This article is available from: http://www.biomedcentral.com/I47I-2334/4/46

(C) 2004 Tumbarello et al; licensee BioMed Central Ltd.

This is an Open Access article distributed under the terms of the Creative Commons Attribution License (http://creativecommons.org/licenses/by/2.0), which permits unrestricted use, distribution, and reproduction in any medium, provided the original work is properly cited.

\begin{abstract}
Background: Diagnosis of HIV infection is recently occurring with increasing frequency in middleaged and in older individuals. As HAART became available, a minimal beneficial effect on immunological outcome in older in respect of younger subjects has been reported. In fact, both the intensity and the rapidity of the immunological response appeared to be reduced in elderly subjects. On the contrary, only few reports have indicated a similar immunological outcome both in older and younger HIV-positive subjects. Interestingly, older age did not seem to significantly affect the long-term virological outcome of HAART treated subjects.

Methods: To characterise epidemiological and clinical features of older HIV+ subjects, a prospective case-control study was performed: 120 subjects $\geq 50$ and 476 between 20 and 35 years were initially compared. Subsequently, to better define the impact of HAART on their viroimmunological response, $8 \mathrm{I}$ older were compared with 162 younger subjects.

Results: At baseline cases presented significantly lower TCD4+ cell number and were more frequently affected by comorbid conditions. Under HAART a statistically significant increase in TCD4+ cell number was observed in cases and controls. At multivariate analysis, there was no statistically significant difference between cases and controls regarding viro-immunological response.
\end{abstract}

Conclusions: Although older subjects present a more severe HIV infection, they can achieve, under HAART, the same viro-immunological success as the younger individuals.

\section{Background}

Early in the epidemic, Human Immunodeficiency Virus (HIV) infection primarily affected young adults; later on, it occurred with increasing frequency in middle-aged and in older individuals, too. In fact, a rate of $12.3 \%$ of AIDS patients aged 50 years or older, with subjects $\geq 60$ years equalling $3.2 \%$, has been recently reported by the Centres for Diseases Control and Prevention (CDC) [1]. 
Most of the known epidemiological features about older HIV-infected subjects, have been defined before the introduction of Highly Active Antiretroviral Therapy (HAART), as the standard therapy for HIV-positive subjects, in 1996. A low level of T CD4+ cells at HIV diagnosis [2,3], a rapid decline of T CD4+ cell count $[4,5]$ and a high level of HIV viral load after seroconversion [6,7] have been reported in older HIV-infected subjects. In addition, these individuals presented a clinical condition of AIDS at the time of diagnosis of HIV infection more frequently than younger [2] and they were more likely to die within one month after HIV diagnosis [8]. Several studies have indicated that older patients had a shorter survival than younger $[2,9,10]$, independently of HIV-risk behaviour $[5,11,12]$ and AIDS-related illnesses [13]. Either the more rapid course $[4,9]$ or the decreased survival $[10,14]$ observed in older subjects were considered to be determined by the more frequent presence of non HIV-related comorbidities.

As HAART became available, a less beneficial effect on immunological outcome in older in respect of younger subjects has been reported [15-17]. In fact, both the intensity $[15,16]$ and the rapidity [17] of the immunological response appeared to be reduced in older subjects. On the contrary, only few reports have indicated a similar immunological outcome both in older and younger HIV-positive subjects $[18,19]$. Interestingly, older age did not seem to significantly affect the long-term virological outcome of HAART treated subjects $[15,18,20]$.

Two were the aims of this study:

1. To characterise the epidemiological and clinical features of older subjects at the time of HIV diagnosis in the HAART era.

2. To better define the impact of HAART on virological and immunological response in a cohort of older HIVpositive patients when confounding variables such as adherence to therapy, side effects and non HIV-related comorbidities were evaluated.

\section{Methods \\ Study setting}

The Catholic University teaching hospital is a 1,900-bed tertiary care centre located in Rome, Italy, with approximately 67,000 patient admissions each year. There is a 60bed unit for the admission of HIV-infected subjects and a day-hospital for out-patient care.

\section{Study design}

Prospective case-control study.

\section{Study population}

All patients presenting the first HIV positive test from January 1997 to June 2003, admitted to our in- and outpatient care, were considered.

For the first aim of the study, subjects aged $\geq 50$ years (older) and between 20 and 35 years (younger) were identified.

For the second aim of the study, older and younger patients who were given HAART regularly and with a follow-up of at least six months, were included as cases and controls, respectively (ratio 1:2). The control group was matched by sex, year of HIV diagnosis, presence of AIDS defining conditions and type of HAART regimen (i.e. NNRTI containing vs. PI containing regimens). A patient (either case or control) was considered as regularly HAART-treated if he/she was under antiretroviral therapy with a combination of two nucleoside reverse transcriptase inhibitors (NRTI) plus either a non nucleoside reverse transcriptase inhibitor (NNRTI) or a protease inhibitor (PI), as single drug or with the addiction of a low dose of ritonavir (i.e. $100 \mathrm{mg}$ bid), for at least three months.

\section{Parameters evaluated}

Patients' records were reviewed by one of us, using a standardised data collection form with predefined criteria. For each subject enrolled in the study, the following data were obtained at inclusion after patient's informed consent: age, gender, HIV-risk behaviour, date of the first available HIV test, reason for HIV testing, CDC stage of HIV infection [21], HIV-related conditions, date of AIDS diagnosis, number of hospitalisations after HIV diagnosis, observed AIDS free interval (i.e. time from HIV infection to AIDS diagnosis), type and use of prophylaxis for Pneumocystis carinii pneumonia (PCP) and toxoplasmosis, antiretroviral therapy (type, duration, adherence and side effects) and other medications (antituberculous drugs, antivirals, corticosteroids, antacids), time of follow-up, time from AIDS diagnosis to death, cause of death.

Data collected from the laboratory records included: numbers of circulating CD4+ T cells $\left(/ \mathrm{mm}^{3}\right), \mathrm{CD} 8+\mathrm{T}$ cells $\left(/ \mathrm{mm}^{3}\right)$ and plasma HIV RNA viral load (copies/ml) with a limit of detection below 50 copies $/ \mathrm{ml}$. The time of the beginning of HAART was considered as time zero in the analysis. All subjects underwent periodical clinical evaluations including determination of CD4+ T cells and HIV viral load every six months.

Adherence was defined through a self-reported evaluation by the patient and registered as percentage by the physician. An evaluation higher than $80 \%$ was classified as "adherent", whereas lower than $80 \%$ was considered as 
"non-adherent". The following adverse effects were considered: anaemia (haemoglobin $<9.0 \mathrm{gr} / \mathrm{dl}$ ), digestive intolerance, dyslipidemia (serum cholesterol >240 mg/dl and/or triglycerides $>200 \mathrm{mg} / \mathrm{dl}$ ), hepatitis, hyperglycaemia (glucose $>150 \mathrm{mg} / \mathrm{dl}$ ), lipodystrophy, pancreatitis, peripheral neuropathy, rash, renal colic and thrombocytopenia (platelets $<50,000$ cells $/ \mathrm{mm}^{3}$ ).

Three outcomes were considered for the study: 1 . Immunological success (IS): defined as T lymphocytes CD4+ cell count $>200 / \mathrm{mm}^{3}$ at the end of the follow-up; 2 . Virological success (VS) defined as a HIV viral load undetectable ( $<50$ copies/ml) at the end of the follow-up; 3. Viroimmunological success (VIS) defined as either undetectable HIV viral load and T lymphocytes CD4+ cell count $>200 / \mathrm{mm}^{3}$ at the end of the follow-up.

\section{Evaluation of comorbidity}

In order to evaluate the significance of non HIV-related comorbid conditions, we used a modified version of the Charlson comorbidity index which excludes AIDS from the diagnosis [22]. Cardiovascular, pulmonary, neurological, endocrine, renal, hepatic, gastrointestinal, rheumatologic diseases, coagulation disorders and cancer were considered as comorbid non HIV-related conditions.

\section{Statistical analysis}

Quantitative variables were tested for normal distribution and compared by means of Student's two tailed t-test. Differences in group proportions were assessed by use of the $\chi^{2}$ test or, for small numbers, Fisher's exact test. Stepwise logistic regression models were used for each factor to adjust for the effects of confounding variables. Two tailed tests of significance at the $\mathrm{p}<0.05$ level were used to determine statistical significance. Statistical analysis was performed using the software program Intercooled Stata 6.0 (Stata Corporation, Texas).

\section{Results}

\section{Epidemiological and clinical features of older patients at the time of HIV diagnosis}

The rate of HIV diagnosis in patients aged $\geq 50$ years admitted to our in- and out-patient care remained constant (about 10\%) over the study-period.

From a total of 1265 subjects with new HIV-positive test, $129(10,1 \%)$ subjects aged $\geq 50$ years were identified. Nine of them were not further considered because of missing data. One hundred twenty older subjects were evaluated. Data were available for 476 younger subjects.

Table I: Demographic and clinical characteristics of older ( $\geq 50$ years) and younger (20-35 years) HIV-positive subjects in the period 1997-2003.

\begin{tabular}{|c|c|c|c|}
\hline & Older $\mathrm{n}=120(\%)$ & Younger $n=476(\%)$ & $P$ \\
\hline Male sex & $91(76)$ & $285(60)$ & $<0.01$ \\
\hline Age (mean $\pm S D)$, years & $58 \pm 5.1$ & $31 \pm 3.2$ & $<0.01$ \\
\hline \multicolumn{4}{|l|}{ Risk factor of HIV infection } \\
\hline Heterosexual & $62(52)$ & $199(42)$ & 0.1 \\
\hline No risk reported & $32(27)$ & $119(25)$ & 0.6 \\
\hline Homosexual & $19(16)$ & $57(12)$ & 0.2 \\
\hline Injection drug users & $6(5)$ & $104(22)$ & $<0.01$ \\
\hline Months between first HIV+ test and AIDS (mean \pm SD) & $1.8 \pm 7.8$ & $3.3 \pm 6.7$ & 0.4 \\
\hline Stage $\mathrm{C}$ of HIV infection* & $62(52)$ & I I 4 (24) & $<0.01$ \\
\hline PCP & $9(8)$ & $14(3)$ & 0.02 \\
\hline HIV encephalopathy & $9(8)$ & $9(2)$ & $<0.01$ \\
\hline Kaposi & $8(7)$ & $5(1)$ & $<0.01$ \\
\hline Candidiasis & $8(7)$ & $43(9)$ & 0.5 \\
\hline Cryptococcosis & $5(4)$ & I $(0.3)$ & $<0.01$ \\
\hline Mycobacteriosis & $4(3)$ & $5(I)$ & 0.2 \\
\hline Cryptosporidiosis & $4(3)$ & $5(1)$ & 0.06 \\
\hline Tuberculosis & $4(3)$ & $14(3)$ & 0.7 \\
\hline Isosporiasis & $I(1)$ & 0 & 0.2 \\
\hline Bacterial pneumonia & $\mathrm{I}(\mathrm{I})$ & 0 & 0.2 \\
\hline Wasting syndrome & $I(I)$ & $9(2)$ & 0.5 \\
\hline Toxoplasmosis & 0 & $9(2)$ & 0.1 \\
\hline Cytomegalovirus retinitis & 0 & $\mathrm{I}(0.3)$ & 0.6 \\
\hline Lymphoma & $7(6)$ & $9(2)$ & 0.05 \\
\hline $\mathrm{CD} 4+\mathrm{T}$ cell $/ \mathrm{mm}^{3}($ mean $\pm \mathrm{SD}) * * *$ & $59.1 \pm 65.3$ & $105.3 \pm 127.4$ & 0.04 \\
\hline Deaths & $16(13)$ & $14(3)$ & $<0.01$ \\
\hline
\end{tabular}

*see Ref. $n^{\circ} 21$; **at AIDS diagnosis; 
Among older subjects there were more males, less intravenous drug abusers, more advanced HIV disease, more frequent $\mathrm{C}$ stage of HIV infection and higher mortality, (Table 1).

The reasons for the first HIV test were comparable both for older and younger subjects. In particular, 30 (25\%) older subjects were asymptomatic. For those who were symptomatic, the more frequently observed symptoms were: fever (25\%), haematological dysfunctions (17\%), weight loss $(14 \%)$, neurological $(8 \%)$, gastrointestinal $(6 \%)$ or hepatic $(7 \%)$ disorders.

Regarding AIDS-defining conditions, a significantly higher frequency of PCP, HIV-encephalopathy, Kaposi's sarcoma and cryptococcosis was observed in older HIVinfected patients than in younger.

\section{Matched case-control study}

Thirty nine out of $120 \mathrm{HIV}$-positive older subjects were not further considered: 29 because the duration of followup was below six months and ten because the case-control matching was not possible. A final number of 81 older patients under regular HAART and with a follow-up of at least six months (cases) were thus compared with 162 younger subjects (controls).

\section{Baseline characteristics and evolution}

Cases had a median age of $56.9 \pm 5.2$ years and controls of $31.3 \pm 3.2$ years. As a result of the matching, $73 \%$ of subjects in both groups were males and 49\% were in CDC stage $\mathrm{C}$ of HIV infection. HIV infection risk factors were similar in the two groups, but eighteen (22\%) cases referred an unknown risk factor compared to $26(16 \%)$ controls $(\mathrm{p}=0.1)$. The mean of CD $4+\mathrm{T}$ cells was significantly lower in cases compared to controls (107 \pm 109 cell $/ \mathrm{mm}^{3}$ vs. $\left.178 \pm 189 \mathrm{cell} / \mathrm{mm}^{3} ; \mathrm{p}<0.01\right)$, such as the mean CD4 percentage ( $9 \%$ vs. $14 \%$; $<<0.01$ ). The mean of CD8+ T cells at baseline was similar in cases and controls $\left(757 \pm 380 \mathrm{cell} / \mathrm{mm}^{3}\right.$ vs. $\left.818 \pm 362\right)(\mathrm{p}=\mathrm{ns})$. Mean of HIV viral load log was similar in the two groups (4.65 \pm 0.57 vs. $4.74 \pm 0.76$ copies $/ \mathrm{ml} ; \mathrm{p}=\mathrm{ns}$ ). No statistical significant difference was observed for haematological parameters, serological markers of previous viral hepatitis (type B or C) and syphilis. Laboratory tests only indicated a significant increase of glycaemia in older patients (103.3 \pm 18.7 vs. $89.0 \pm 10.6 \mathrm{mg} / \mathrm{dl} ; \mathrm{p}<0.01)$.

Follow-up was similar in the two groups ( $40 \pm 13$ vs. $42 \pm$ 11 months; $\mathrm{p}=\mathrm{ns}$ ), ranging from 6 to 78 months.

No differences were observed between cases and controls in the number of hospitalisations $(1.2 \pm 2.1$ vs. $1.3 \pm 2.8$; $\mathrm{p}=\mathrm{ns})$.

Seven (9\%) and six (4\%) patients died in the case and control groups, respectively $(\mathrm{p}=\mathrm{ns})$. All causes of death in both groups were HIV-related conditions with the exception of one case who died for an acute mesenteric vascular episode.

Table 2: Antiretroviral therapy in 81 cases and 162 controls

\begin{tabular}{|c|c|c|c|}
\hline & Cases n (\%) & Controls n (\%) & $P$ \\
\hline First line therapy & $81(100)$ & $162(100)$ & \\
\hline \multicolumn{4}{|l|}{ Combinations } \\
\hline$-\mathrm{NRTI}+\mathrm{PI}$ & $67(83)$ & $138(85)$ & 0.7 \\
\hline$-\mathrm{NRTI+NNRTI}$ & $14(17)$ & $26(16)$ & 0.7 \\
\hline Duration; months (mean $\pm \mathrm{SD}$ ) & $13.46 \pm 10.23$ & $16.67 \pm 8.45$ & 0.06 \\
\hline $\mathrm{N}^{\circ}$ of patients who suspended & $53(66)$ & $91(56)$ & 0.2 \\
\hline \multicolumn{4}{|l|}{ Cause of suspension } \\
\hline -side effects & $30(56)$ & $37(4 I)$ & 0.1 \\
\hline -viro-immunological failure & $8(15)$ & $15(17)$ & 0.6 \\
\hline Second line therapy & $45(56)$ & $91(56)$ & 1 \\
\hline Third line therapy & $11(14)$ & $31(19)$ & 0.4 \\
\hline Total number of drug changes (mean $\pm \mathrm{SD}$ ) & $2.1 \pm 0.9$ & $2.0 \pm 0.6$ & 0.8 \\
\hline Adherent to the last drug regimen & $68(84)$ & $118(73)$ & 0.08 \\
\hline \multicolumn{4}{|l|}{ Side effects to HAART } \\
\hline dyslipidemia & $32(40)$ & $55(34)$ & 0.5 \\
\hline digestive intolerance & $26(32)$ & $58(36)$ & 0.6 \\
\hline lipodystrophy & $12(15)$ & $23(14)$ & 0.7 \\
\hline hyperglycaemia & $8(10)$ & $3(2)$ & 0.01 \\
\hline anaemia & $8(10)$ & $3(2)$ & 0.01 \\
\hline
\end{tabular}




\section{Comorbid conditions}

Cases had more comorbid conditions than controls (45.6\% vs. $15.9 \%$; $\mathrm{p}<0.01)$. One third of the cases suffered from cardiovascular diseases, a rare condition among controls (32.2\% vs. 2.1\%; p < 0.01). Gastrointestinal disorders $(9.4 \%$ vs. $1.2 \% ; \mathrm{p}=0.04)$ and diabetes (11.0\% vs. $2.1 \%$; $=0.02$ ) were also significantly more frequent among cases than controls. No statistically significant differences were found for cancer, pulmonary, renal or endocrine diseases, chronic hepatitis and coagulation disorders. The total comorbid points were 37 for cases and 20 for controls. Cases had also a higher mean Charlson index in respect to controls $(0.57 \pm 0.92$ vs. $0.12 \pm 0.44 ; \mathrm{p}$ $<0.01)$.

\section{Antiretroviral therapy}

No statistically significant difference between cases and controls was observed in type, number and duration of HAART regimens. The first line antiretroviral therapy included PI in more than $80 \%$ of cases and controls (Table 2). The patients who required a change in antiretroviral therapy (second line therapy) received a therapeutical cocktail including PI in $40 \%$ vs. $48 \%(\mathrm{p}=\mathrm{ns})$ and NNRTI in $57 \%$ vs. $50 \%$ ( $\mathrm{p}=\mathrm{ns}$ ) of cases and controls, respectively. Similar percentages were observed in the patients who required another change of antiretroviral therapy (third line therapy) during the follow-up. In the first line drug regimen, side effects were more frequently responsible of the change of the drug regimen in cases compared with controls, although not reaching a statistically significant level $(\mathrm{p}=0.1)$. A high level of adherence to HAART was observed in both groups (82\% vs. $75 \%$; p $=\mathrm{ns}$ ). The more frequent adverse reactions were dyslipidemia, digestive intolerance and lipodystrophy in both groups $(\mathrm{p}=\mathrm{ns})$. A significantly higher frequency of hyperglycaemia and anaemia was observed in cases than in controls (Table 2).

\section{Immunological and virological response} HAART related immunoreconstitution

Comparing the mean values obtained at baseline in both cases and controls with those obtained at the end of the follow-up, a statistically significant increase in T CD4+ cell number was observed. In particular, T CD4+ cell count increased in 48 months from $107 \pm 109$ to $476 \pm$ 258 for cases $(\mathrm{p}=0.04)$, and from $178 \pm 189$ to $584 \pm 252$ for controls $(\mathrm{p}<0.01)$. There was always a progressive linear enhancement in both groups at any individual time of the follow-up. The lower values observed in cases in respect to controls at baseline, persisted until the end of the follow-up (Figure 1).

The increasing value of $\mathrm{T}$ CD4+ cell count every six months in respect to baseline was comparable in the two groups (Figure 2).
According to the above mentioned outcome definition, IS was observed in 59 (73\%) of the cases and 128 (79\%) of the controls $(\mathrm{p}=\mathrm{ns})$. The following variables were significantly associated with IS at univariate analysis: CDC stage A $(p=0.01)$, low Charlson index $(p=0.01), C D 4+T$ cell count at the beginning and at $6,12,18,24,30,36$ months of HAART $(\mathrm{p}<0.01)$, months to achieve CD4+ T cell $>200 /$ $\mathrm{mm}^{3}(\mathrm{p}<0.01)$, enhancement of CD4+ T cell count in the first six months ( $\mathrm{p}<0.01)$, HIV viremia at 30 months ( $\mathrm{p}$ $<0.01)$.

\section{HAART related viral suppression}

A statistically significant reduction of HIV viral load was observed in both cases and controls when comparing baseline with the end of the follow-up values. In particular, means of HIV-RNA viral load log decreased in 48 months from $4.74 \pm 0.57$ to $2.01 \pm 0.4$ copies $/ \mathrm{ml}$ in cases $(\mathrm{p}<0.01)$ and from $4.69 \pm 0.76$ to $1.6 \pm 0.2$ copies $/ \mathrm{ml}$ in controls $(\mathrm{p}<0.01)$.

HIV viral load reduced under antiretroviral therapy in both groups in a comparable manner. In fact, there was no statistically significant difference between cases and controls at any individual time of the follow-up (Figure 3).

According to the above mentioned outcome definition, VS was observed in 66 (82\%) of cases and 121 (75\%) of controls $(\mathrm{p}=\mathrm{ns})$. The following variables were significantly associated with VS at univariate analysis: CDC stage A $(p=0.02)$, high adherence to HAART $(p=0.01)$, dyslipidemia as adverse effect of HAART ( $p=0.01)$, HIV viral load at $6(\mathrm{p}<0.01)$ and 24 months $(\mathrm{p}=0.02)$.

\section{HAART related virological and immunological outcome}

According to our definition of the outcome, VIS was observed in 53 (66\%) of cases and 100 (62\%) of controls $(\mathrm{p}=\mathrm{ns})$. The following variables were significantly associated with VIS at univariate analysis: CDC stage A ( $\mathrm{p}<$ $0.01)$, high adherence to HAART $(\mathrm{p}=0.02)$, dyslipidemia as adverse effect of HAART $(\mathrm{p}<0.01), \mathrm{CD} 4+\mathrm{T}$ cell number at baseline and at $6,12,18,24,30,36$ months of HAART $(\mathrm{p}<0.01)$, enhancement of CD $4+\mathrm{T}$ cellcount in the first six months $(\mathrm{p}<0.01)$, HIV viral load at $6(\mathrm{p}=$ $0.04)$ and 30 months $(\mathrm{p}=0.01)$.

No statistical difference in immuno-virological response was found between cases and controls when, as cases, only a subgroup of patients aged $>60$ years was considered (data not shown).

\section{Multivariate analysis}

In a multivariate logistic regression model, after adjustment for sex and Charlson index, there was no statistically significant difference between cases and controls for IS, VS and VIS $(\mathrm{p}=\mathrm{ns})$. Similar results were obtained when CDC 


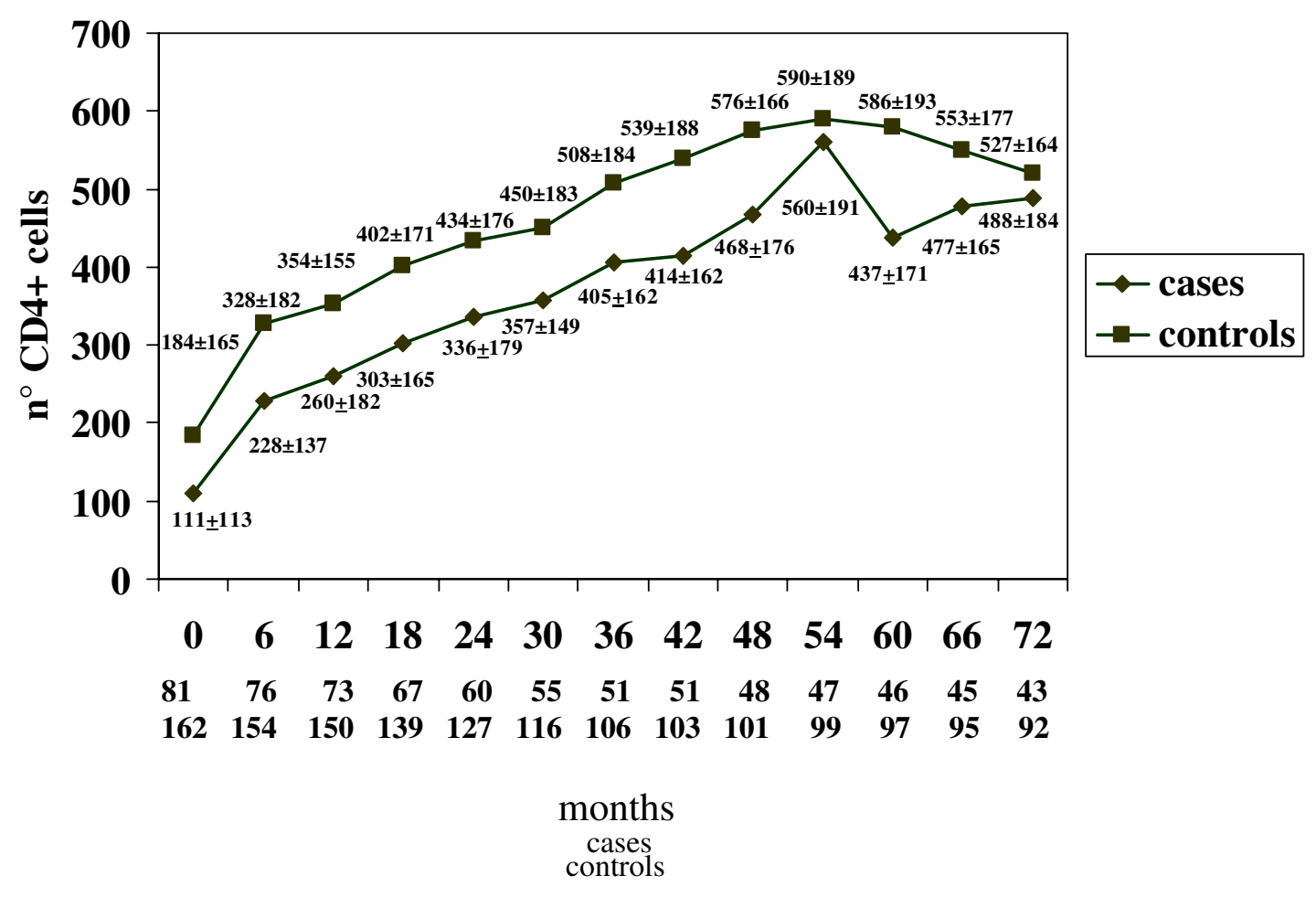

Figure I

$\mathrm{T}$ CD4+ cell count $/ \mathrm{mm}^{3}$ (mean $\pm \mathrm{SD}$ ) at the beginning of HAART and each six months of follow-up in cases and controls.

stage A and CD4+ T cell count at HIV diagnosis were added to the model.

Another model including sex, Charlson index, CDC stage A, CD4+ T cell count at the beginning of HAART, adherence and dyslipidemia as adverse effect of HAART did not show any statistically significant difference between cases and controls for IS, VS and VIS.

Further adjustment for sex, Charlson index, CDC stage A, adherence, dyslipidemia as adverse effect of HAART, CD4+ T cell count at beginning of HAART and after six months of therapy, enhancement of CD4+ T cell count in the first six months, months to achieve CD $4+\mathrm{T}$ cell count $>200 / \mathrm{mm}^{3}$, HIV viral load at six months did not modify the results.

\section{Discussion}

This study, conducted in an Italian population, shows that in the HAART era, the percentage of older patients out of the new HIV infections is approximately $10 \%$, slightly higher than previously reported [23]. The impact of long term HAART-related immunoreconstitution in this subpopulation of HIV patients could reduce the incidence of older patients with AIDS within the next years to less than the $12 \%$ recently reported [1].

The first part of our study confirms previous pre-HAART era observations, about more severe HIV infection in older subjects [2-10]. In fact, higher frequency of patients with AIDS at HIV diagnosis, lower T CD4+ cell count and higher mortality in older subjects in respect of younger were observed. A late diagnosis or a more aggressive 


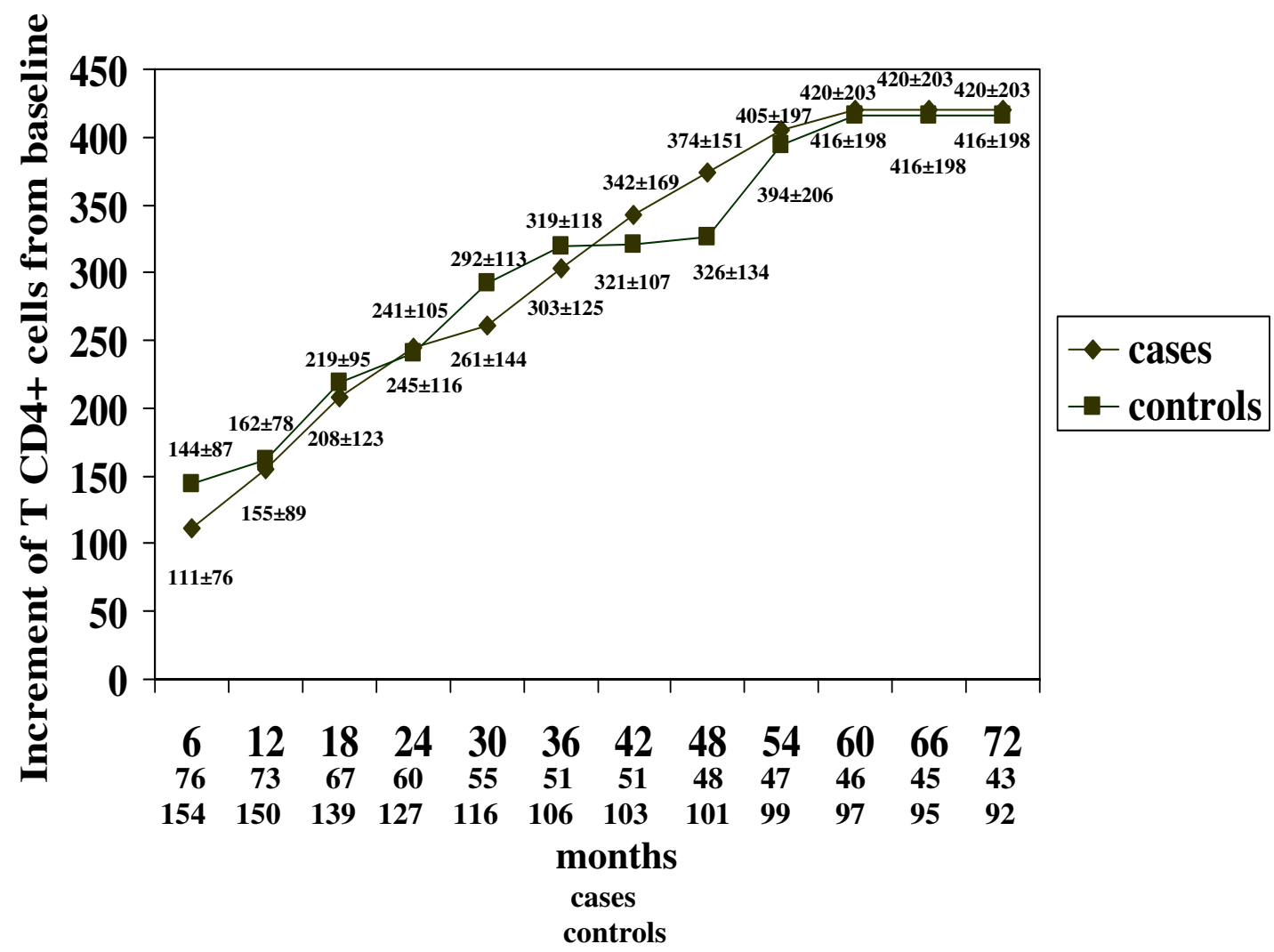

Figure 2

T CD4+ cell count/mmc six month increment (mean \pm SD) from the beginning of HAART to the end of the follow-up in cases and controls

impact of HIV infection in older population could explain these results. The first possibility could reflect low level information and/or physicians' insufficient suspicion $[2,24]$, despite the world-wide durable informative campaigns and preventive efforts on this issue. Alternatively, a shorter or less symptomatic pre-AIDS phase, as already reported in older HIV-positive subjects, could contribute to the late diagnosis [2]. On the other hand, the more aggressive impact of HIV infection in older population has been related to the hypothesis that HIV is an additional aggravating factor to an already debilitated host potentially presenting numerous comorbidities, less physiological reserves $[10,14]$ and a less responsive immune system [2,25]. In fact, in HIV-negative older subjects, important changes in cellular and humoral components of the immune system including defects in T CD4+ lymphocyte function, have been described [26].

Regarding HIV-risk behaviour, our data indicate the heterosexual route as the most frequent in older patients, followed by no risk reported, homosexual contacts, intravenous drug abuse. In particular, our data confirm recent reports $[8,27]$ indicating an increased incidence of HIV subjects with no risk reported. This aspect could contribute to the above mentioned low level of suspicion of HIV diagnosis in older subjects. It is of interest that a large 


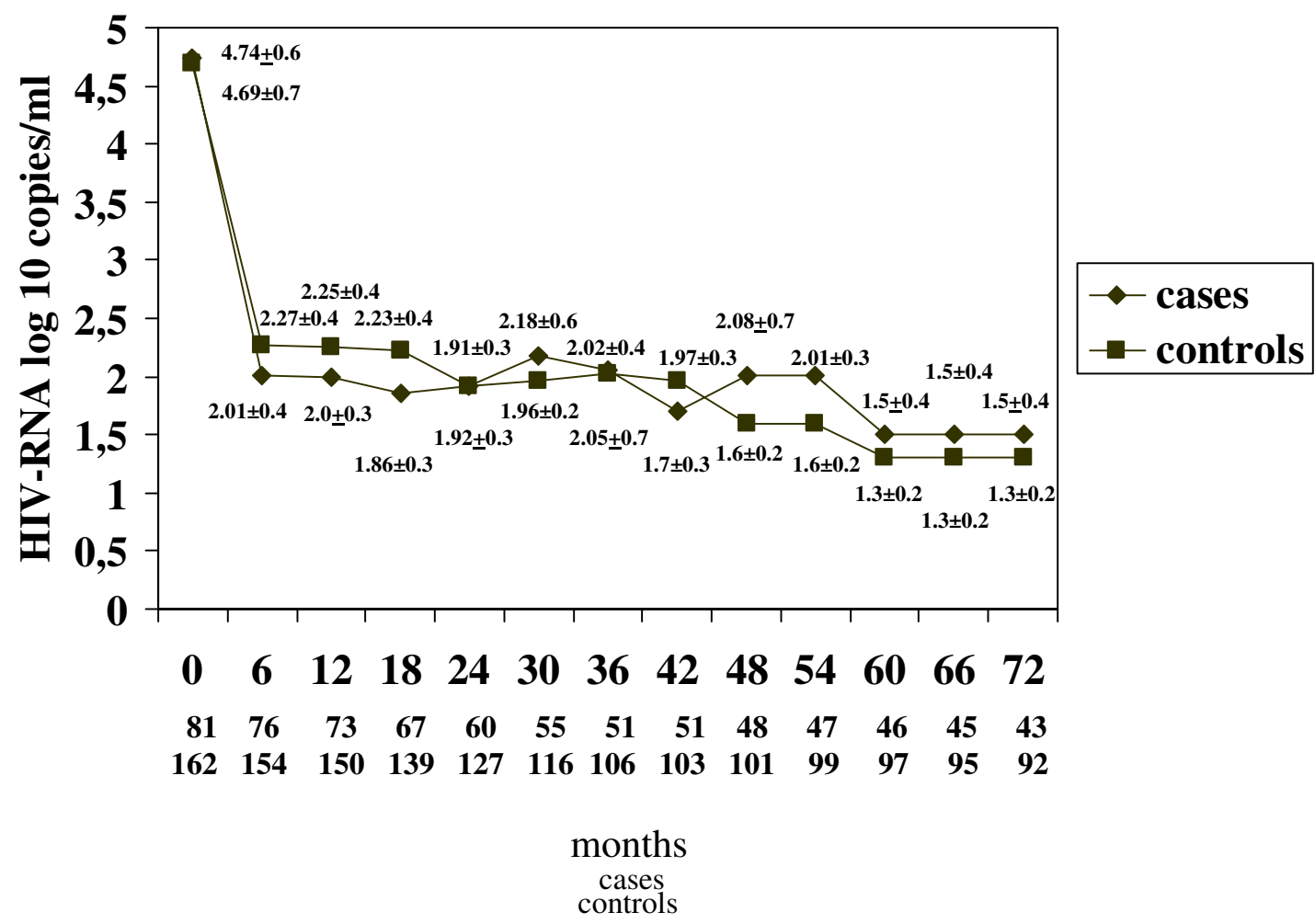

Figure 3

Comparison of HIV-RNA log 10 (mean \pm SD) between cases and controls from baseline to the end of follow-up.

epidemiological survey in the US general population has reported a prevalence of at least one risk factor for HIV infection in about $10 \%$ of subjects aged 50 years or older [28].

To date, no studies have indicated that older AIDS patients should be treated differently for HIV disease. Clinical drug trials often exclude older patients because of multiple medical problems, comorbidities or co-existing non HIV-related medication regimens [29]. The first available literature data obtained in a large population of HIVpositive patients treated with zidovudine in the early nineties showed that age was an independent predictor of rapid progression to AIDS and shorter survival [30]. On the contrary, antiretroviral therapy was the only inde- pendent predictor of survival after the diagnosis of AIDS in older HIV-positive subjects in the pre HAART era [31].

Very little literature and study has been devoted specifically to the role of protease inhibitors and aggressive antiretroviral triple therapy in elderly patients. Few data have been published concerning the specific response of older patients to new HIV antiretroviral treatments, and currently there are no guidelines for specific antiretroviral treatment modalities for patients $>50$ years of age. However, a poor immunological response under HAART was observed in small groups of patients $[15,16]$ possibly due to the well known depressed thymic function of the elderlies [15-17]. Only few reports showed a similar virological 
and immunological outcome in older HIV-positive compared with younger subjects $[18,19]$.

This six year prospective matched case control study not only confirms this observation but indicates that older patients under HAART experienced a successful immunological response comparable to younger subjects also in a long term follow-up, in line with preliminary reports [3234]. In fact, our older patients, starting HAART with a lower level of T CD4+ cells than younger, obtained a significant increment in their T CD4+ cell count, with the same rapidity, intensity and persistence in time as observed in younger patients.

Meticulous adherence to HAART is necessary to achieve an optimal clinical and virological response. A variety of factors may predict medication adherence among HIVinfected adults. Although older age is usually associated with higher rates of antiretroviral adherence, older participants who were cognitively impaired could have difficulty in adequately adhering to their medication regimen [35-37]. Our findings indicate that this goal could be achieved independently from age. In fact, although thymic functions decline with age, substantial output of $\mathrm{T}$ CD4+ cells can be maintained into late adulthood, thus contributing to HAART-related immune recovery in older HIV-positive patients [38-40].

Early work also demonstrated a positive association between age and the plasma HIV-1-RNA copy number at the time of identification of HIV-1 serostatus among recently diagnosed older HIV-1 positive individuals [41]. However, this could have been caused by a lead-time diagnostic bias, with a greater delay among older individuals.

No differences were observed in virological response as indicated by viral load reduction in older patients with respect to younger. This result is in line with previous reports $[15,18]$ including a large study which indicated that older age decreases the risk to have viral load greater than 1000 copies/ml in HIV-positive subjects under HAART [2]. In a recent report, older age was associated with lower levels of HIV-1 replication, independent of antiretroviral therapy usage, regimen adherence, and diseases stage. It is suggested that the effect may be caused by changes in viral evolution or immunological monitoring specific to older individuals with HIV-1 infection [42].

In our study both the frequency and the distribution of adverse effects of HAART were similar between the two groups, with the exception of anaemia and hyperglycaemia which were more frequent in older patients. Hyperglycaemia can be explained because diabetes is a frequent comorbid condition among older. Older subjects were more susceptible than younger to adverse effects in the first line therapy; consequently they had to change therapy more frequently.

Univariate analysis showed an association of low Charlson index with immunological success. However, considering that the Charlson index was higher in older patients, none of the models of multivariate analysis indicated an association between comorbidity and virological and/or immunological response. Nonetheless previous studies have suggested a more rapid course and a decreased survival in older HIV-positive patients because of the presence of comorbidities [10], our data did not confirm this association (data not shown). Interestingly, cardiovascular disease and diabetes were the more frequent comorbidities in our older population.

Dyslipidemia and lipodystrophy in association with gastrointestinal disorders were the more frequent adverse reactions. In view of these results, of the recent reports of endothelial vascular damage, premature atherosclerosis and coronary events in younger HAART-treated patients [43-45], an important increase of cardiovascular event incidence in older HIV-positive patients under HAART could not be excluded to occur in the forthcoming years.

\section{Conclusions}

In conclusion, we strongly underline the need for an early diagnosis of HIV infection in older subjects through implementation of educational campaigns specifically targeted to this population. In relation to older people, physicians should consider more often the possibility of HIV diagnosis, through more screening and counselling. An early diagnosis is mandatory because, although older subjects present with more severe HIV infection, the use of HAART allow them to achieve the same viro-immunological response as younger individuals. At present, there is an increasing number of older subjects living with HIV either because of new HIV diagnosis in older population or because who have previously acquired HIV infection now become older due to HAART improved survival. It is reasonable to predict that the average age of chronically treated HIV-positive patients will progressively increase in the forthcoming years. Based on this reality, ageing with HIV is a newly manifested chronic disease with a complex long-term management in consideration also of the impact of HIV and HAART on the natural history of other chronic diseases typically associated with older age.

\section{List of abbreviations}

CDC Centers for Diseases Control

HAART Highly Active Antiretroviral Therapy

NRTI Nucleoside Reverse Trascriptase Inhibitor 
NNRTI Non Nucleoside Reverse Trascriptase Inhibitor

PI Protease Inhibitor

VIS Viro Immunological Success

VS Virological Success

IS Immunological Success

\section{Competing interests}

The author(s) declare that they have no competing interests.

\section{Authors' contributions}

MT conceived the study, performed the statistical analysis and wrote the manuscript

RR participated in the design of the study, in the collection of the data, in the statistical analysis and in the writing of the manuscript

KdGD participated in the design of the study, in the collection of the data and in the writing of the manuscript

SB participated in the design of the study and in the collection of the data

EM participated in the collection of the data

ET participated in the collection of the data

ET participated in the design of the study

RC did the supervision and critically read the last version of the paper

All authors read and approved the final manuscript

\section{References}

I. Centers for Disease Control and Prevention: HIV and AIDSUnited States, I98I-2000. Morb Mortal Wkly Rep 200I, 50:430-434.

2. Ferro S, Salit IE: HIV infection in patients over $\mathbf{5 5}$ years of age. J Acquir Immune Defic Syndr 1992, 5:348-355.

3. Ena J, Valls V, Lopez Aldeguer J, Garcia Gasco MP, Anon S, Navarro V, Sanchez R, Boix V, Portilla J, Roig P, Masia MM, Maestre Peiro A: Clinical presentation of HIV infection in patients aged 50 years or older. J Infect 1998, 37:213-216.

4. Phillips AN, Lee CA, Elford J, Webster A, Janossy G, Timms A, Bofill $M$, Kernoff $\mathrm{PB}$ : More rapid progression to AIDS in older HIVinfected people: the role of CD4+ T-cell counts. J Acquir Immune Defic Syndr 199I, 4:970-975.

5. Operskalski EA, Stram DO, Lee H, Zhou Y, Donegan E, Busch MP, Stevens CE, Schiff ER, Dietrich SL, Mosley JW: Human immunodeficiency virus type I infection: relationship of risk group and age to rate of progression to AIDS. J Infect Dis 1995, I 72:648-655.

6. O'Brien TR, Blattner WA, Waters D, Eyster E, Hilgartner MW, Cohen AR, Luban N, Hatzakis A, Aledort LM, Rosenberg PS, Miley WJ, Kroner BL, Goedert J]: Serum HIV-I RNA levels and time to development of AIDS in the Multicenter Hemophilia Cohort Study. JAMA 1996, 276:105-II0.

7. Soriano V, Castilla J, Gomez-Cano M, Holguin A, Villalba N, Mas A, Gonzalez-Lahoz J: The decline in CD4+ $T$ lymphocytes as a function of the duration of HIV infection, age at seroconversion, and viral load. J Infect 1998, 36:307-3II.

8. Ship JA, Wolff A, Selik RM: Epidemiology of acquired immune deficiency syndrome in persons aged $\mathbf{5 0}$ years or older. J Acquir Immune Defic Syndr 1991, 4:84-88.

9. Carre N, Deveau C, Belanger F, Boufassa F, Persoz A, Jadand C, Rouzioux C, Delfraissy JF, Bucquet D: Effect of age exposure group on the onset of AIDS in heterosexual and homosexual HIVinfected patients. AIDS 1994, 8:797-802.

10. Skiest DJ, Rubinstien E, Carley N, Gioiella L, Lyons R: The importance of comorbidity in HIV-infected patients over 55: a retrospective case-control study. Am J Med 1996, I 0 I:605-6II.

II. Darby SC, Ewart DW, Giangrande PLF, Spooner RJ, Rizza CR: Importance of age at infection with HIV-I for survival and development of AIDS in UK haemophilia population. Lancet 1996, 347:1573-1579.

12. Tumbarello M, Tacconelli E, Cauda R, Ortona L: Age as a prognostic factor in AIDS. Lancet 1996, 348:623-624.

13. Baslev U, D'Arminio Monforte A, Stergiou G, Antunes F, Mulcahy F, Pehrson PO, Phillips A, Pedersen C, Lundgren JD: Influence of age on rates of new AIDS defining diseases and survival in 6546 AIDS patients. Scand J Infect Dis 1997, 29:337-343.

14. Butt AA, Dascomb KK, De Salvo KB, Bazzano L, Kissinger PJ, Szerlip HM: Human immunodeficiency virus infection in elderly patients. South Med J 200I, 94:397-400.

15. Manfredi R, Chiodo F: A case control study of virological and immunological effects of highly active antiretroviral therapy in HIV-infected patients with advanced age. AIDS 2000, I 4: |475- 477.

16. Goetz MB, Boscardin WJ, Wiley D, Alkasspooles S: Decreased recovery of CD4 lymphocytes in older HIV-infected patients beginning highly active antiretroviral therapy. AIDS 200I, I5:1576-1579.

17. Viard JP, Mocroft A, Chiesi A, Kirk O, Roge B, Panos G, Vetter N, Bruun JN, Johnson M, Lundgren JD: EuroSIDA Study Group: Influence of age on CD4 cell recovery in human immunodeficiency virus-infected patients receiving highly active antiretroviral therapy: evidence from the EuroSIDA study.J Infect Dis 200I, I 83:1290-1294.

18. Knobel H, Guelar A, Valldecillo G, Carmona A, Gonzalez A, LopezColomes JL, Saballs P, Gimeno JL, Diez A: Response to Highly Active Antiretroviral Therapy in HIV-infected patients aged 60 years or older after $\mathbf{2 4}$ months follow-up. AIDS 200I, I5:1591-1593.

19. Grimes RM, Otiniano ME, Rodriguez-Barradas MC, Lai D: Clinical experience with human immunodeficiency virus-infected older patients in the era of effective antiretroviral therapy. Clin Infect Dis 2002, 34: I530-I533.

20. Paredes R, Mocroft A, Kirk O, Lazzarin A, Barton SE, van Lunzen J, Katzenstein TL, Antunes F, Lundgren JD, Clotet B: Predictors of virological success and ensuing failure in HIV-positive patients starting Highly Active Antiretroviral Therapy in Europe. Arch Intern Med 2000, I 60: I I 23-I I 32.

21. Centers for Disease Control and Prevention: 1993 Classification system for HIV infection and expanded surveillance case definition for AIDS among adolescents and adults. Morb Mortal Wkly Rep 1992, 41: I-19.

22. Charlson ME, Pompei P, Ales KL, MacKenzie CR: A new method of classifying prognostic comorbidity in longitudinal studies: development and validation. J Chron Dis 1987, 40:373-383.

23. Inungu JN, Mokotoff ED, Kent JB: Characteristics of HIV infection in patients fifty years or older in Michigan. AIDS Patient Care STDs 200I, I 5:567-573.

24. El-Sadr W, Gettler J: Unrecognized Human Immunodeficiency Virus infection in the elderly. Arch Intern Med 1995, I 55: I84-I86.

25. Adler WH, Baskar PV, Chrest FJ, Dorsey-Cooper B, Winchurch RA, Nagel JE: HIV infection and aging: mechanisms to explain the accelerated rate of progression in the older patient. Mech Ageing Dev 1997, 96:137-155.

26. Ginaldi L, De Martinis M, D'Ostilio A, Marini L, Loreto MF, Martorelli $\checkmark$, Quaglino D: The immune system in the elderly. Immunol Res 1999, 20:109-115. 
27. Centers for Disease Control and Prevention: AIDS among persons aged $\geq \mathbf{5 0}$ years- United States, I 99 I-I996. Morb Mortal Wkly Rep 1998, 47:21-27.

28. Stall $R$, Catania J: AIDS risk behaviour among late middle-aged and elderly americans. Arch Intern Med I994, I 54:57-63.

29. Chiao EY, Ries KM, Sande MA: AIDS and the elderly. Clin Infect Dis 1999, 28:740-745.

30. Vella S, Giuliano M, Floridia M, Chiesi A, Tomino C, Seeber A, Barcherini S, Bucciardini R, Mariotti S: Effect of sex, age and transmission category on the progression to AIDS and survival of zidovudine-treated symptomatic patients. AIDS 1995, 9:5I-56.

31. Keller MJ, Hausdorff JM, Kyne L, Wei JY: Is age a negative prognostic indicator in HIV infection or AIDS? Aging (Milano) 1999, I | :35-38.

32. Tumbarello M, Rabagliati R, de Gaetano Donati K, Bertagnolio S, Tamburrini E, Tacconelli E, Cauda R: Older HIV-positive subjects in the HAART era: changing of a scenario. AIDS 2003, I7:|28-|3|.

33. Skiest DJ: The importance of co-morbidity in older HIVinfected patients. AIDS 2003, I 7:1577.

34. Adeyemi OM, Badri SM, Max B, Chinomona N, Barker D: HIV infection in older patients. CID 2003, 36: 1347.

35. Paterson DL, Swindells S, Mohr J, Brester M, Vergis EN, Squier C, Wagener MM, Singh N: Adherence to protease inhibitor therapy and outcomes in patients with HIV infection. Ann Intern Med 2000, I33:21-30.

36. Cingolani A, Antinori A, Rizzo MG, Murri R, Ammassari A, Baldini F, Di Giambenedetto S, Cauda R, De Luca A: Usefulness of monitoring HIV drug resistance and adherence in individuals failing highly active antiretroviral therapy: a randomized study. AIDS 2002, 16:369-379.

37. Hinkin $\mathrm{CH}$, Hardy DJ, Mason KI, Castellon SA, Durvasula RS, Lam MN, Stefaniak M: Medication adherence in HIV-infected adults: effect of patient age, cognitive status, and substance abuse. AIDS 2004, I 8(SuppI I):S19-S25

38. Renaud M, Katlama C, Mallet A, Calvez V, Carcelain G, Tubiana R, Jouan M, Caumes E, Agut H, Bricaire F, Debre P, Autran B: Determinants of paradoxical CD4 cell reconstitution after protease inhibitor-containing antiretroviral regimen. AIDS 1999, 13:669-676.

39. Douek DC, McFarland RD, Keiser PH, Gage EA, Massey JM, Haynes BF, Polis MA, Haase AT, Feinberg MB, Sullivan JL, Jamieson BD, Zack JA, Picker LJ, Koup RA: Changes in thymic function with age and during the treatment of HIV infection. Nature 1998, 396:690-695.

40. Carcelain G, Debré P, Autran B: Reconstitution of CD4+ T lymphocytes in HIV-infected individuals following antiretroviral therapy. Curr Opin Immunol 200 I, I 3:483-488.

4I. Operskalsky EA, Mosley JW, Busch MP, Stram DO: Influences of age, viral load and CD4+ count on the rate of progression of HIV-I infection to AIDS. J Acquired Immune Defic Syndr Hum Retrovirol 1997, I 5:243-244.

42. Goodkin K, Shapshak P, Asthana D, Zheng W, Concha M, Wilkie FL, Molina R, Lee D, Suarez P, Symes S, Khamis I: Older age and plasma viral load in HIV-I infection. AIDS 2004, I 8(Suppl I):S87-S98.

43. de Gaetano Donati K, Rabagliati R, Tumbarello M, Tacconelli E, Amore C, Cauda R, lacoviello L: Increased soluble markers of endothelial dysfunction in HIV-positive patients under Highly Active Antiretroviral Therapy. AIDS 2003, 1 7:765-768.

44. Laurence J: Vascular complications associated with use of HIV protease inhibitors. Lancet 1998, 35 I:1960.

45. Henry K, Melroe H, Huebsch J, Hermundson J, Levine C, Swensen L, Daley J: Severe premature coronary artery disease with protease inhibitors. Lancet I998, $35 \mathrm{I}: 1328$.

\section{Pre-publication history}

The pre-publication history for this paper can be accessed here:

http://www.biomedcentral.com/1471-2334/4/46/prepub
Publish with Biomed Central and every scientist can read your work free of charge

"BioMed Central will be the most significant development for disseminating the results of biomedical research in our lifetime. "

Sir Paul Nurse, Cancer Research UK

Your research papers will be:

- available free of charge to the entire biomedical community

- peer reviewed and published immediately upon acceptance

- cited in PubMed and archived on PubMed Central

- yours - you keep the copyright
BioMedcentral 